\title{
PENGEMBANGAN APLIKASI KARTU RENCANA STUDI ONLINE PADA JURUSAN PENDIDIKAN LUAR SEKOLAH UNIVERSITAS PALANGKA RAYA
}

Widiatry ${ }^{\text {a, } 1, *}$

${ }^{a}$ Universitas Palangka Raya, Kampus Tunjung Nyaho Jalan Yos Sudarso, Palangka Raya, Kalimantan Tengah, Indonesia

1 widiatry@it.upr.ac.id*

* corresponding author

ARTICLE INFO

\section{Keywords}

"Kartu Rencana Studi"

Online

Waterfall

\section{ABSTRACT}

Kartu Rencana Studi is an important activity carried out by students to determine the courses to be taken in the following semester, the process of filling out Kartu Rencana Studi is done one week before the lecture is really active and if students do not fill out in accordance with applicable regulations, the student concerned is considered on college leave. In the Department of Non-School Education, the University of Palangka Raya to fill in Kartu Rencana Studi still uses a manual method where students consult with their academic supervisor to ask for approval of the courses to be programmed in the semester that will take place. In the implementation of this filling process can cause problems, one of which is the delay of students in completing Kartu Rencana Studi, it is difficult to control the courses taken by students, not all courses that want to be programmed in accordance with the courses issued and there are some specific subjects who experience conflicts on the same scheduled day and hour make students have to readjust the schedule and courses to be taken with the available schedule.

This research design made up of two stages: (1) data collection and analysis conducted by means of literature study and observation, (2) applying the waterfall method already modified with the stages is system analysis, design, implementation and testing. The implementation uses PHP and Mysql as a database to store data. Furthermore, at this testing stage using the Blackbox method.

\section{Pendahuluan}

Kartu Rencana Studi (KRS) merupakan kegiatan penting yang dilakukan oleh mahasiswa untuk menentukan mata kuliah yang akan diambil pada semester berikutnya, proses pengisian KRS dilakukan satu minggu sebelum perkuliahan benar-benar aktif dan jika mahasiswa tidak mengisi KRS sesuai dengan ketentuan yang berlaku maka mahasiswa yang bersangkutan dianggap cuti kuliah.

KRS online merupakan transisi dari sistem manual ke sistem online untuk membantu penginputan KRS manual supaya informasi yang dihasilkan kepada mahasiswa tepat dan hasil dari pengisian KRS online ini bisa dipertanggungjawabkan karena dilakukan secara langsung oleh mahasiswa dan hasil dari pengisian KRS tersebut bisa disimpan datanya dalam bentuk database dan dapat digunakan sebagaimana mestinya jika diperlukan dikemudian hari. Kelebihan media online dalam bentuk website adalah kemampuan interaktif dan penyebaran informasi yang sangat cepat.

Untuk melakukan pengisian KRS pada jurusan Pendidikan Luar Sekolah, Universitas Palangka Raya masih menggunakan sistem manual. Dimana dalam pelaksanaan proses pengisiannya menimbulkan masalah yaitu antara lain keterlambatan mahasiswa dalam mengisi KRS, sulit mengontrol mata kuliah yang diambil mahasiswa, tidak semua mata kuliah yang ingin diprogramkan sesuai dengan mata kuliah yang dikeluarkan dan ada beberapa mata kuliah tertentu yang mengalami 
bentrok pada hari dan jam dijadwal yang sama yang membuat mahasiswa harus menyesuaikan kembali jadwal dan mata kuliah yang akan diambil dengan jadwal yang tersedia.

Untuk mengatasi permasalahan tersebut maka dibuatlah suatu penelitian untuk mengembangkan sebuah aplikasi KRS online yang dapat digunakan oleh mahasiswa pada Jurusan Pendidikan Luar Sekolah Universitas Palangka Raya pada saat pengisian KRS. Aplikasi dibuat menggunakan bahasa pemrograman PHP dan database MySQL [1].

Beberapa penelitian telah dilakukan sebelumnya oleh peneliti yang digunakan untuk menambah pengetahuan dalam mengembangkan aplikasi KRS online ini, yaitu Rancang Bangun Website Sistem Informasi Praktikum Jurusan Teknik Informatika Universitas Palangka Raya (Widiatry, 2017) dan Rancang Bangun Website E-Learning SMAN 1 Palangka Raya (Widiatry \&Agra, 2018) yang dapat menambah pemahaman dalam menganalisis dan mendesain suatu aplikasi online berbasis website $[2][3]$.

\section{Metodologi Penelitian}

Dalam penelitian ini, rancangan penelitian yang dibuat terdiri atas dua tahap yaitu: (1) pengumpulan dan analisis data yang dilakukan dengan cara studi pustaka dan observasi, (2) menerapkan metode waterfall [4] yang sudah dimodifikasi dengan tahap-tahapnya adalah analisis sistem, desain, implementasi dan pengujian. Implementasi menggunakan PHP dan Mysql sebagai database untuk menyimpan data. Selanjutnya pada tahapan testing Aplikasi ini menggunakan metode Blackbox [5][6][7]. Model yang digunakan merupakan suatu hasil dari siklus hidup pengembangan perangkat lunak [8]. Berikut ini merupakan beberapa tahapan penelitiannya, yaitu:

\subsection{Studi Pustaka dan Observasi}

Metode ini melakukan studi pustaka terhadap buku dan jurnal ilmiah sebagai pendukung dalam penelitian bagaimana mengembangkan Aplikasi Kartu Rencana Studi Online Pada Jurusan Pendidikan Luar Sekolah Universitas Palangka Raya. Observasi dilakukan untuk mengetahui datadata apa saja yang diperlukan untuk melalukan proses pengisian KRS.

\subsection{Analisis Sistem}

Proses pencarian kebutuhan difokuskan pada aplikasi KRS online untuk mengetahui sifat dari aplikasi yang akan dibuat, pemodelan proses bisnis menggunakan Data Flow Diagram (DFD) dan Entity Relationship Diagram (ERD) [9].

\subsection{Desain Sistem}

Proses ini digunakan untuk membuat blueprint aplikasi seperti perancangan basis data dan perancangan interface.

\subsection{Implementasi}

Proses yang akan dilakukan yaitu pembuatan aplikasi sesuai dengan perancangan basis data dan interface yang telah dilakukan pada tahap sebelumnya.

\subsection{Pengujian Sistem}

Proses pengujian akan dilakukan dengan metode Blackbox testing yang disertai dengan melakukan simulasi data. Pengujian Blackbox adalah pengujian aspek fundamental sistem tanpa memperhatikan struktur logika internal suatu aplikasi [10]. Metode ini digunakan untuk mengetahui apakah aplikasi berfungsi dengan benar [7].

\section{Hasil dan Pembahasan}




\subsection{Proses Bisnis Aplikasi KRS Online Bagi Mahasiswa}

Proses bisnis sistem baru dalam proses pengisian KRS bagi mahasiswa jurusan Pendidikan Luar Sekolah adalah sebagai berikut :

1) Mahasiswa login ke aplikasi

2) Pilih mata kuliah yang akan diprogramkan

3) Cek mata kuliah prasyarat dari mata kuliah yang diprogramkan

4) Cek apakah jadwal kuliah ada yang bentrok atau tidak

5) Cek jumlah SKS yang diijinkan, jika jumlah SKS yang diprogramkan kurang atau sama dengan SKS yang diijinkan maka pengisian KRS telah selesai

\subsection{Proses Bisnis Aplikasi KRS Online Bagi Admin}

Proses bisnis sistem baru dalam proses pengisian KRS admin pada jurusan Pendidikan Luar Sekolah adalah sebagai berikut :

1) Admin login ke sistem.

2) Admin mengelola data sebagai berikut :

a. Data akun.

b. Data tahun akademik.

c. Data mata kuliah.

d. Data dosen pa.

e. Data mahasiswa.

3) Admin logout dari sistem

\subsection{Proses Bisnis Aplikasi KRS Online Bagi Staff Jurusan}

Proses bisnis sistem baru dalam proses pengisian KRS bagi staff jurusan Pendidikan Luar Sekolah adalah sebagai berikut :

1) Staff jurusan login ke sistem.

2) Staff dapat mengelola data, data tersebut meliputi :

a. Data akun.

b. Data khs, staff dapat mencetak khs mahasiswa.

c. Data dpna, staff dapat mengelola dan mencetak dpna.

3) Staff logout dari sistem.

\subsection{Diagram Konteks}

Menggambarkan seluruh proses yang terdapat dalam sebuah aplikasi, diagram ini tidak memuat penyimpanan karena semua entitas eksternal yang ditujukan pada diagram konteks berisi aliran-aliran data utama menuju sistem dan dari sistem. Diagram konteks untuk Aplikasi KRS Online dapat dilihat pada gambar 1 di bawah ini. 


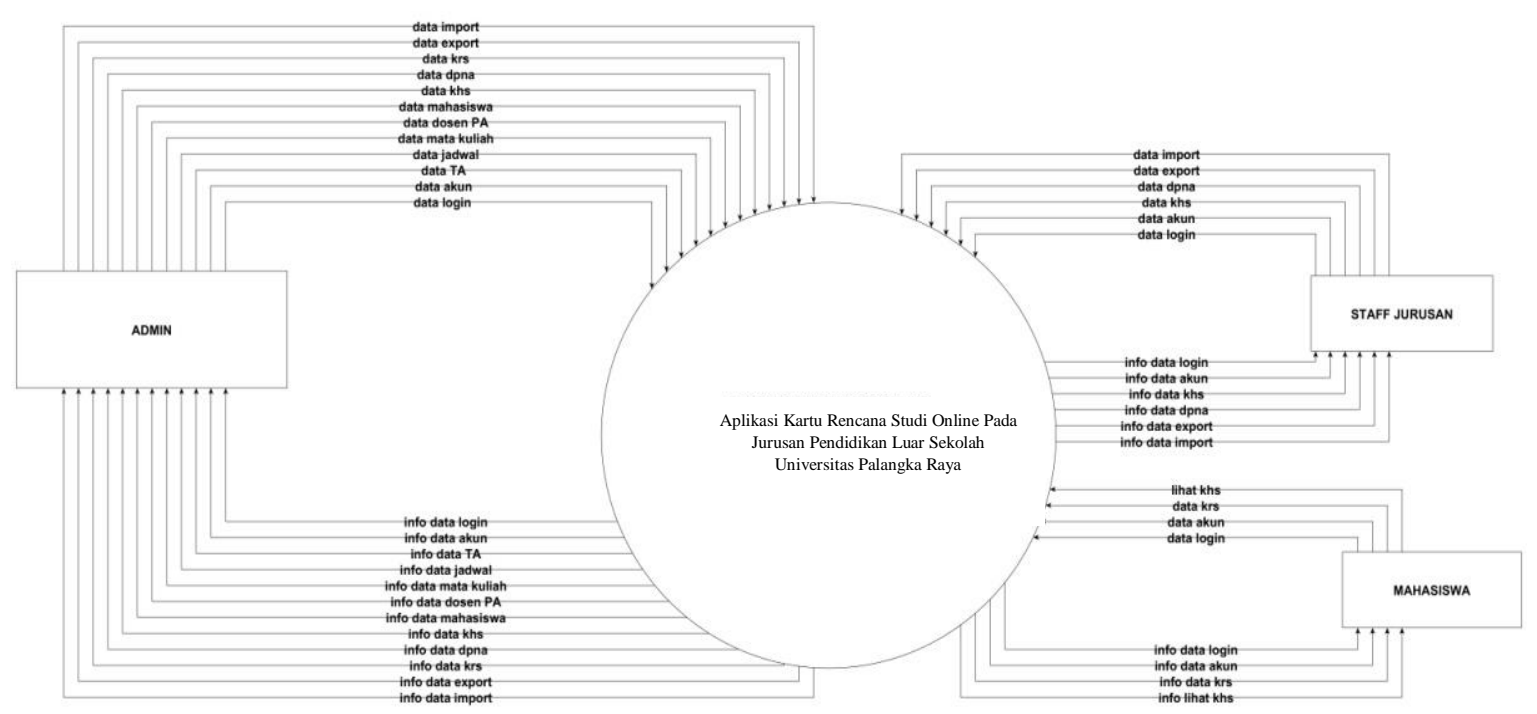

Gambar 1. Diagram Konteks Aplikasi KRS Online

\subsection{Data Flow Diagram Level 1}

Data Flow Diagram (DFD) level 1 merupakan penjabaran dari diagram konteks Aplikasi KRS online, yang berisi semua proses yang ada dalam aplikasi beserta dengan entitas dan data store yang ada. DFD level 1 untuk Aplikasi KRS Online dapat dilihat pada gambar 2 di bawah ini.

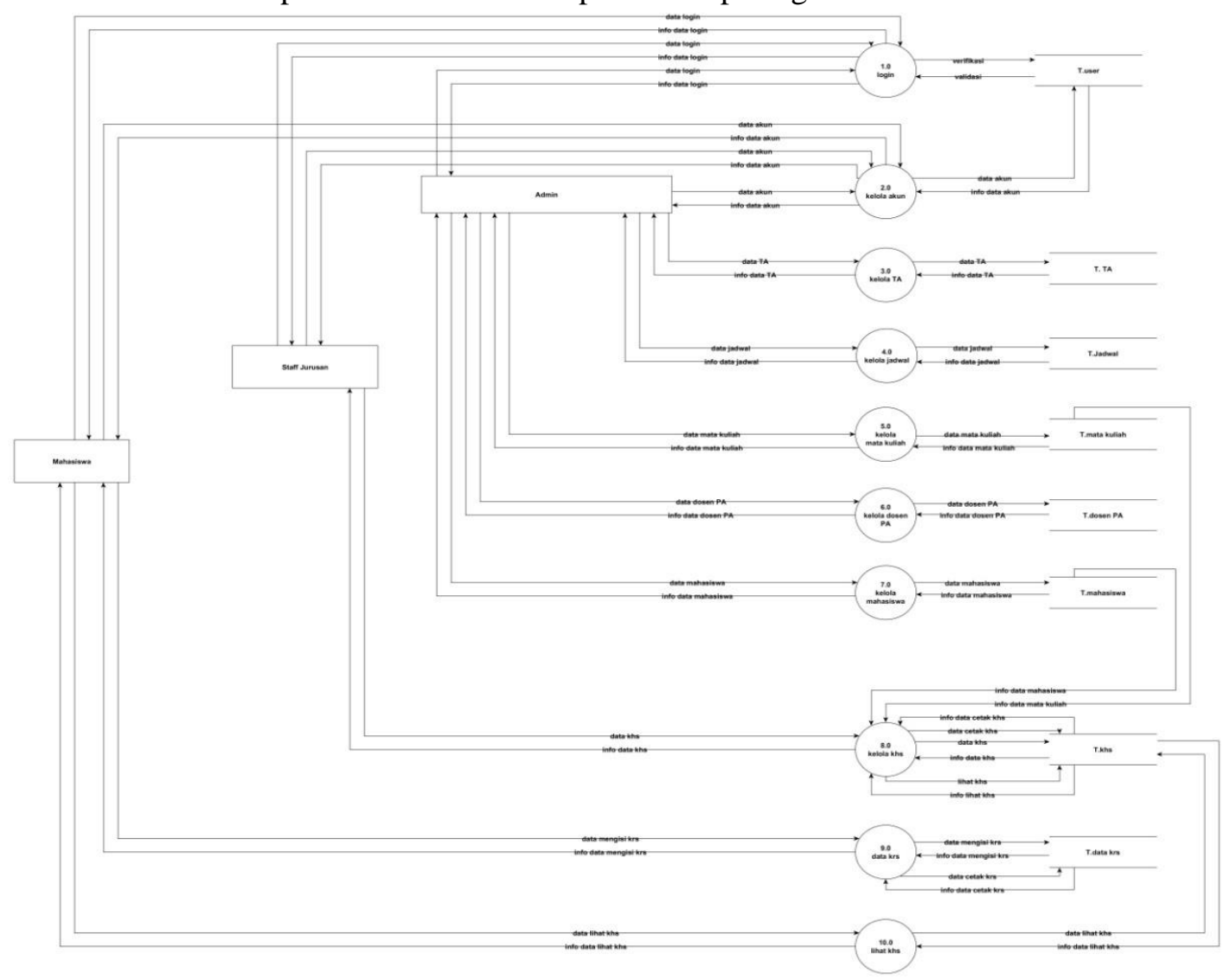

Gambar 2. DFD Level 1 


\subsection{Entity Relationship Diagram}

Entity Relationship Diagram (ERD) merupakan model penggambaran data dalam bentuk entitas, atribut dan hubungan antar entitas dalam sistem secara keseluruhan. ERD untuk Aplikasi KRS Online dapat dilihat pada gambar 3 di bawah ini.

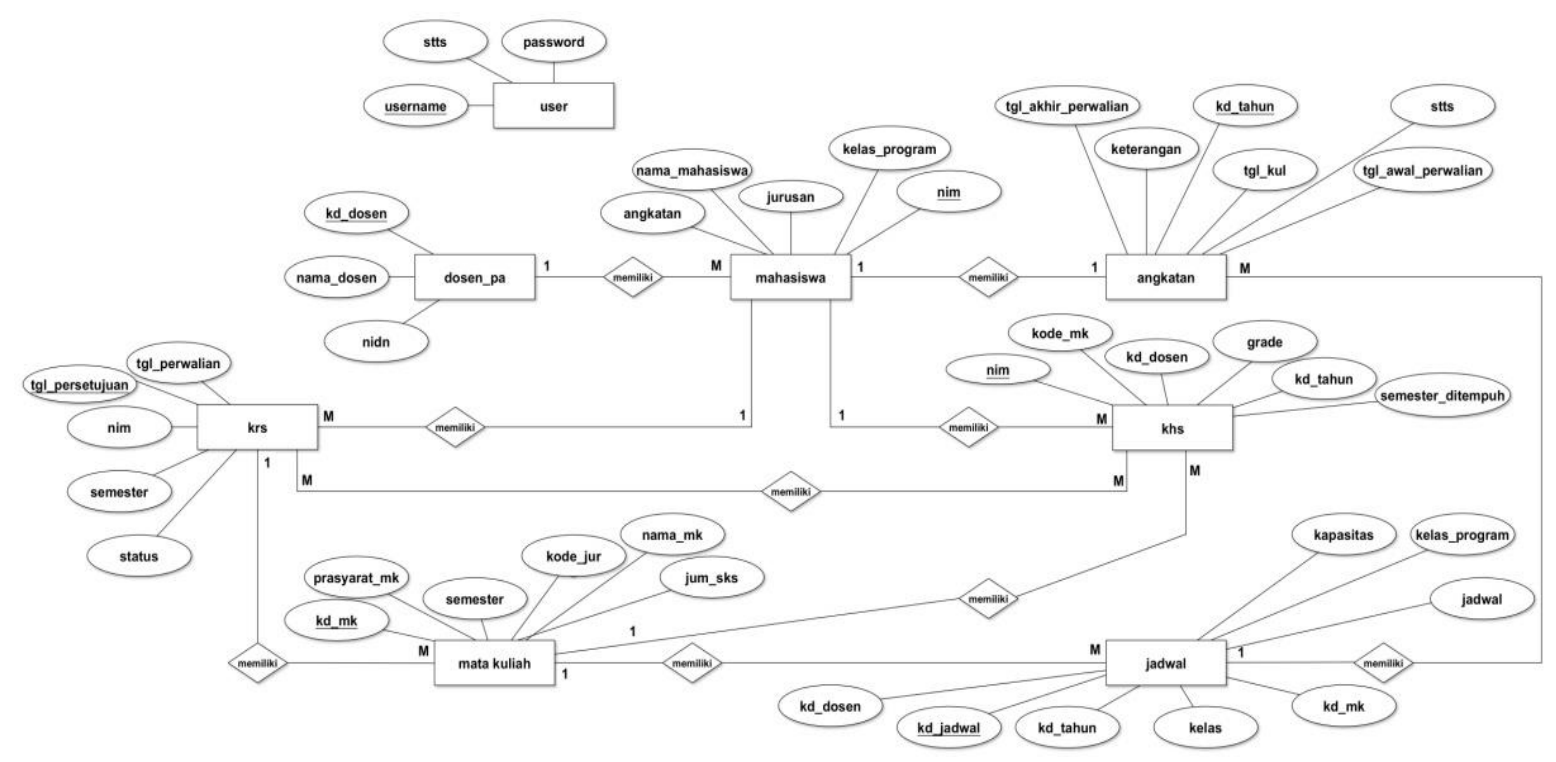

Gambar 3. ERD Aplikasi KRS Online

\subsection{Perancangan Antarmuka Aplikasi}

\subsubsection{Antarmuka Halaman Admin}

Pada gambar 4 di bawah ini merupakan halaman beranda untuk Admin. Halaman beranda akan tampil ketika admin berhasil login, dalam halaman ini menampilkan fitur-fitur yang dapat diakses dan dikelola oleh admin. Admin dapat mengelola data tahun akademik, data jadwal, data mata kuliah, data dosen PA, data Mahasiswa dan data Staff jurusan.

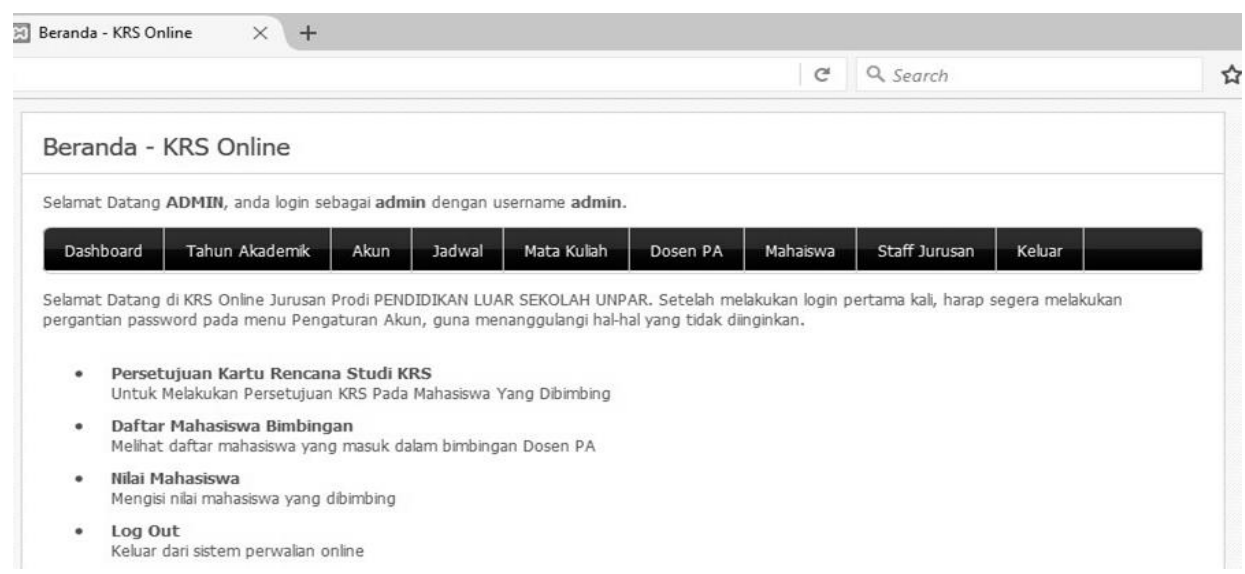

Gambar 4. Antarmuka Halaman Admin 


\subsubsection{Antarmuka Halaman Staff Jurusan}

Pada gambar 5 di bawah ini merupakan halaman beranda untuk Staff jurusan. Halaman beranda akan tampil ketika Staff jurusan berhasil login, dalam halaman ini menampilkan fitur-fitur yang dapat diakses dan dikelola oleh Staff jurusan yaitu data KRS, data KHS dan data DPNA.

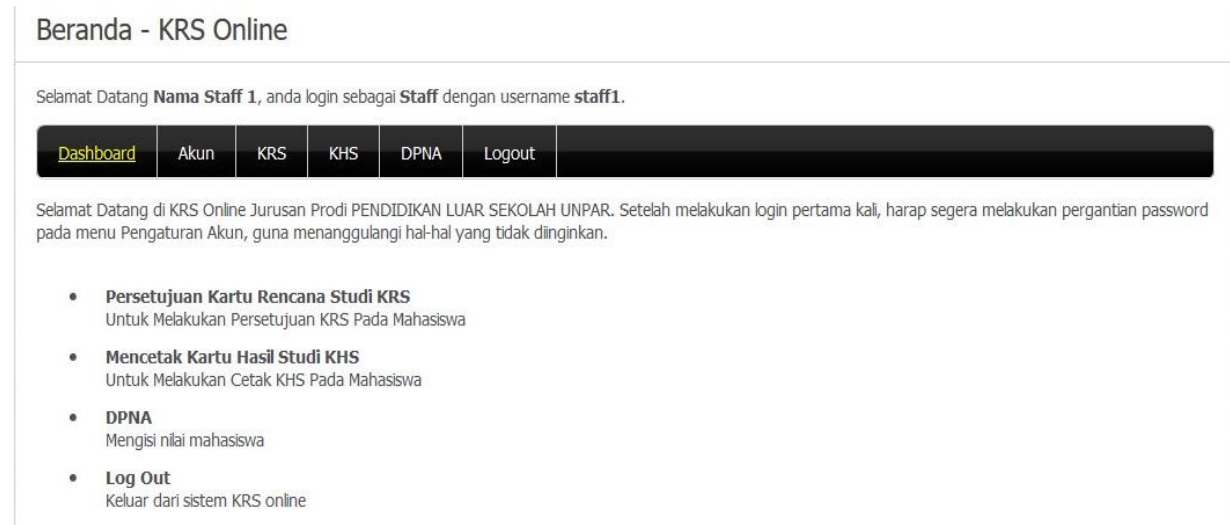

Gambar 5. Antarmuka Halaman Staff Jurusan

\subsubsection{Antarmuka Halaman Mahasiswa}

Pada gambar 6 di bawah ini merupakan halaman beranda untuk mahasiswa. Halaman beranda akan tampil ketika mahasiswa berhasil login, dalam halaman ini menampilkan fitur-fitur yang dapat diakses dan dikelola oleh mahasiswa yaitu kelola Kartu Rencana Studi dan melihat Kartu Hasil Studi.

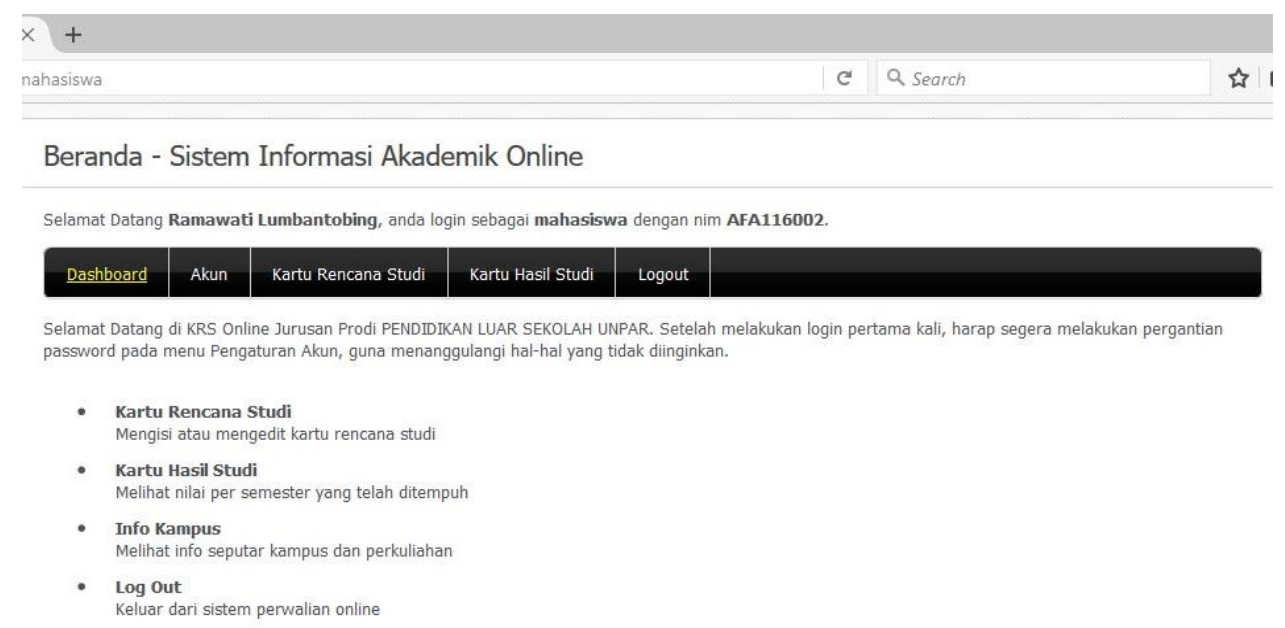

Gambar 6. Antarmuka Halaman Mahasiswa

\subsubsection{Antarmuka Halaman Pengisian KRS Mahasiswa}

Pada gambar 7 di bawah ini mahasiswa dapat melalukan pengisian KRS yang berisi mata kuliah yang akan deprogramkan pada semester yang akan berjalan. 


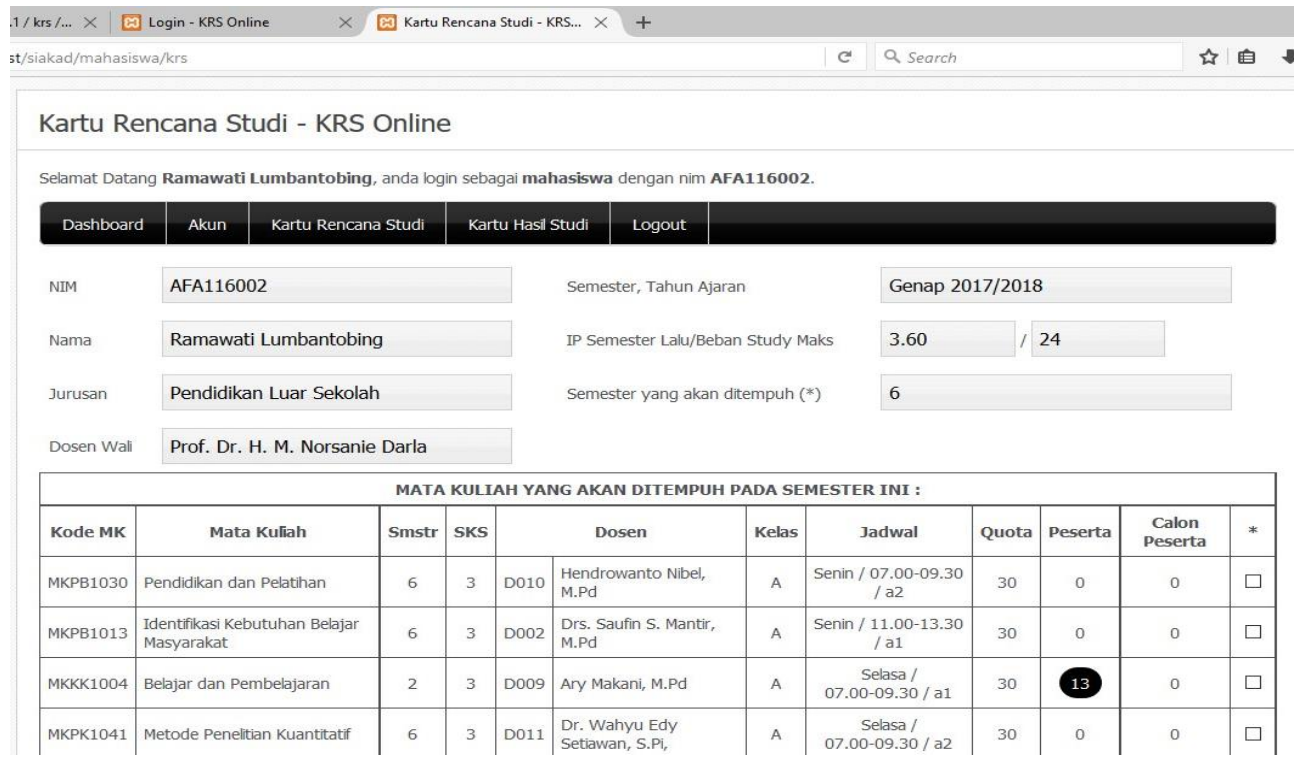

Gambar 7. Antarmuka Halaman Pengisian KRS Mahasiswa

\subsubsection{Antarmuka Halaman Cetak KRS}

Pada gambar 8 di bawah ini mahasiswa dapat melakukan proses cetak KRS dari pengisisan KRS yang telah berhasil dilakukan. 


\section{JURNAL TEKNOLOGI INFORMASI}

Jurnal Keilmutan dan Aplikasi Bidang Teknik Informatika

[E-ISSN 2656-0321]

[Vol 14 No 1]

[ Januari 2020]

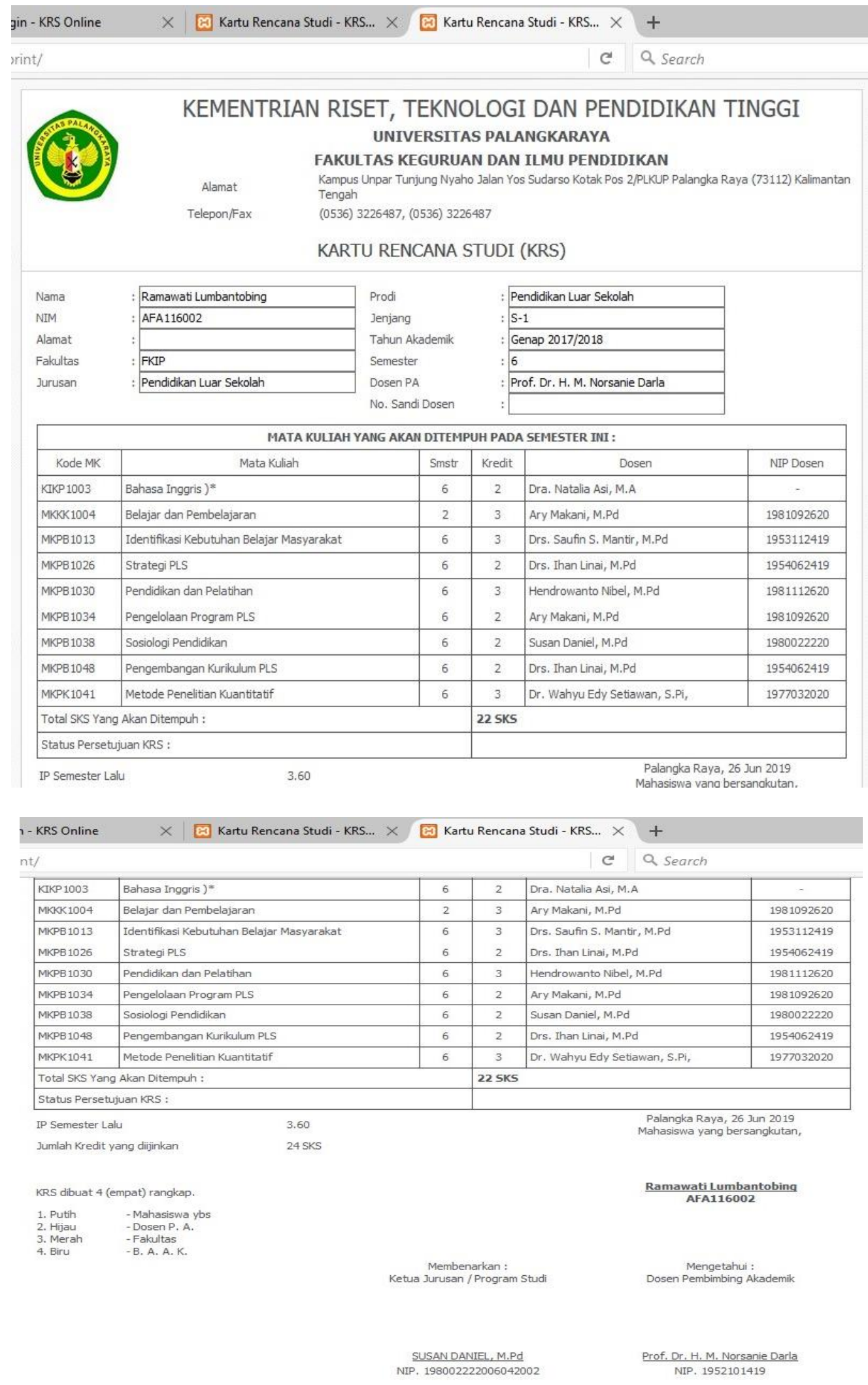

Gambar 8. Antarmuka Halaman Cetak KRS 


\subsubsection{Antarmuka Halaman KHS}

Pada gambar 9 di bawah ini mahasiswa dapat mencetak KHS dari perkuliahan yang telah dilalui pada setiap semester.

\begin{tabular}{|c|c|c|c|c|c|c|c|}
\hline 23 & МКРВ1019 & Sosiologi Kota dan Desa & 3 & 2 & A & 4 & 8 \\
\hline 24 & MKКк1002 & Profesi Pendidikan & 3 & 3 & $\mathrm{~B}+$ & 3.5 & 10.5 \\
\hline \multicolumn{4}{|c|}{ Jumlah SKS : 23} & \multicolumn{4}{|c|}{ IP Semester : 3.46} \\
\hline \multicolumn{8}{|c|}{ Semester : 4} \\
\hline 25 & MKPB1032 & Analisa Sistem PLS & 4 & 3 & B & 3 & 9 \\
\hline 26 & MKPB1025 & Organisasi dan Kepemimpinan PLS & 4 & 2 & $B+$ & 3.5 & 7 \\
\hline 27 & KIKP1002 & Bahasa Indonesia $)^{*}$ & 4 & 2 & $\mathrm{~B}+$ & 3.5 & 7 \\
\hline 28 & MKPB1050 & Penyuluhan Sosial & 4 & 2 & A & 4 & 8 \\
\hline 29 & MKPB1029 & Metode PLS-PM & 4 & 3 & $\mathrm{~B}+$ & 3.5 & 10.5 \\
\hline 30 & MKPB1031 & Diagnosa dan Terapi Masalah Sosial & 4 & 3 & $\mathrm{~B}+$ & 3.5 & 10.5 \\
\hline 31 & MKPB1042 & Metode Penelitian Kualitatif & 4 & 3 & c & 2 & 6 \\
\hline 32 & MKКК1023 & Perubahan Sosial & 4 & 2 & B & 3 & 6 \\
\hline \multicolumn{4}{|c|}{ Jumlah SKS : 20} & \multicolumn{4}{|c|}{ IP Semester : 3.2} \\
\hline \multicolumn{8}{|c|}{ Semester : 5} \\
\hline 33 & MKКK1003 & Perkembangan Peserta Didik & 5 & 2 & $\mathrm{~B}+$ & 3.5 & 7 \\
\hline 34 & MKPB1027 & Pengembangan Bahan Belajar PNF/PLS dan Media PNF/PLS & 5 & 4 & $B+$ & 3.5 & 14 \\
\hline 35 & MKPB1009 & Pengembangan SDM PNF/PLS & 5 & 2 & A & 4 & 8 \\
\hline 36 & MKPB1011 & Pendidikan Orang Dewasa & 5 & 2 & $B+$ & 3.5 & 7 \\
\hline \multicolumn{4}{|c|}{ Jumlah SKS : 10} & \multicolumn{4}{|c|}{ IP Semester : 3.6} \\
\hline
\end{tabular}

Gambar 9. Antarmuka Halaman KHS

\subsection{Blackbox Testing}

Blackbox testing adalah pengujian yang dilakukan untuk membuktikan bahwa aplikasi KRS online ini telah berfungsi dengan baik dan untuk mengetahui kebenaran fungsi serta alur program. Pada tabel 1 di bawah ini dapat dilihat hasil dari blackbox testing pada halaman Admin. Pada tabel 2 di bawah ini dapat dilihat hasil dari blackbox testing pada halaman Staff Jurusan. Pada tabel 3 di bawah ini dapat dilihat hasil dari blackbox testing pada halaman Mahasiswa.

Tabel 1. Blackbox Testing Menu Halaman Admin

\begin{tabular}{|c|l|l|c|}
\hline No & \multicolumn{1}{|c|}{ Halaman } & \multicolumn{1}{c|}{ Proses } & Hasil \\
\hline 1 & Login admin & Menginputkan username dan password & Sesuai \\
\hline 2 & Dashboard & Menampilkan halaman utama admin & Sesuai \\
\hline 3 & Tahun Akademik & Menampilkan halaman Tahun Akademik & Sesuai \\
\hline 4 & Akun & Menampilkan halaman akun & Sesuai \\
\hline 5 & Jadwal & Menampilkan halaman jadwal & Sesuai \\
\hline 6 & Mata kuliah & Menampilkan halaman mata kuliah & Sesuai \\
\hline 7 & Dosen PA & Menampilkan halaman dosen PA & Sesuai \\
\hline 8 & Mahasiswa & Menampilkan halaman mahasiswa & Sesuai \\
\hline 9 & Staff jurusan & Menampilkan halaman staff jurusan & Sesuai \\
\hline 10 & Logout & Keluar (Admin ke halaman login) & Sesuai \\
\hline
\end{tabular}


Tabel 2. Blackbox Testing Menu Halaman Staff Jurusan

\begin{tabular}{|c|l|l|c|}
\hline No & \multicolumn{1}{|c|}{ Halaman } & \multicolumn{1}{c|}{ Proses } & Hasil \\
\hline 1 & Login staff jurusan & Menginputkan username dan password & Sesuai \\
\hline 2 & Dashboard & Menampilkan halaman utama staff jurusan & Sesuai \\
\hline 3 & Akun & Menampilkan halaman akun & Sesuai \\
\hline 4 & KRS & Menampilkan halaman krs & Sesuai \\
\hline 5 & KHS & Menampilkan halaman khs & Sesuai \\
\hline 6 & DPNA & Menampilkan halaman dpna & Sesuai \\
\hline 7 & Logout & Keluar (Staff Jurusan ke halaman login) & Sesuai \\
\hline
\end{tabular}

Tabel 3. Blackbox Testing Menu Halaman Mahasiswa

\begin{tabular}{|c|l|l|c|}
\hline No & \multicolumn{1}{|c|}{ Halaman } & \multicolumn{1}{c|}{ Proses } & Hasil \\
\hline 1 & Login mahasiswa & Menginputkan username dan password & Sesuai \\
\hline 2 & Dashboard & Menampilkan halaman utama mahasiswa & Sesuai \\
\hline 3 & Akun & Menampilkan halamanakun & Sesuai \\
\hline 4 & KRS & Menampilkan halaman KRS & Sesuai \\
\hline 5 & KHS & Menampilkan halaman KHS & Sesuai \\
\hline 6 & Logout & Keluar (Mahasiswa ke halaman login) & Sesuai \\
\hline
\end{tabular}

\section{Kesimpulan}

Pengembangan aplikasi KRS online ini dibuat dengan dua tahap yaitu : (1) pengumpulan dan analisis data yang dilakukan dengan cara studi pustaka dan observasi, (2) menerapkan metode waterfall yang sudah dimodifikasi dengan tahap-tahapnya adalah analisis sistem, desain, implementasi dan pengujian. Implementasi menggunakan PHP dan Mysql sebagai database untuk menyimpan data. Selanjutnya pada tahapan testing aplikasi ini menggunakan metode Blackbox. Berdasarkan hasil pengujian yang dilakukan maka aplikasi ini dapat berjalan dengan baik untuk pengguna admin, mahasiswa dan staff jurusan. Untuk pengembangan selanjutnya diharapkan aplikasi ini dibuat berbasis android dengan menambahkan fitur untuk membuat jadwal pengganti matakuliah pada sistem agar dapat menangani jika ada waktu mata kuliah yang berbenturan dengan hari libur.

\section{Daftar Pustaka}

[1] Agung dan Hikmah Baitul dkk. (2015). Cara Cepat Membangun Website Dari Nol. ANDI. Yogyakarta.

[2] Widiatry, W. (2017). Rancang Bangun Website Sistem Informasi Praktikum Jurusan Teknik Informatika Univeritas Palangka Raya. Jurnal SAINTEKOM, 6(2), 12-24.

[3] Widiatry, W., \& Nugraha, A. (2018). RANCANG BANGUN WEBSITE E-LEARNING SMAN 1 PALANGKA RAYA. JURNAL TEKNOLOGI INFORMASI, 12(1), 57-62.

[4] Pressman, S. Roger. (2010). Pendekatan Praktisi Rekayasa Perangkat Lunak. Edisi 7. Penerbit Andi. Yogyakarta. Halaman 45-46.

[5] Pranatawijaya, V. H., Putra, P. B. A. A., \& Patianom, A. J. (2018). RANCANG BANGUN APLIKASI PEMETAAN GEDUNG UNIVERSITAS PALANGKA RAYA PADA SUB. BAG BARANG MILIK NEGARA (BMN) BUK UNIVERSITAS PALANGKA RAYA. JURNAL TEKNOLOGI INFORMASI, 12(2), 74-79.

[6] Pranatawijaya, V. H., Widiatry, W., Sari, N. N. K., \& Putra, P. B. A. A. (2019). Sistem Informasi Geografis Mencari Rute Lokasi Travel Di Kota Palangka Raya Berbasis Website. Jurnal Teknologi Informasi, 13(1), 71-78. 
[7] Sari, N. N. K., Putra, P. B. A. A., \& Christian, E. (2019). RANCANG BANGUN APLIKASI MOBILE LEARNING TENSES BAHASA INGGRIS. JURNAL TEKNOLOGI INFORMASI, 13(2), 37-46.

[8] Arcisphere technologies. (2012). Tutorial: The Software Development Life Cycle (SDLC). Softwarelifecyclepros.

[9] Rosa, A.S dan M. Shalahuddin. (2013). Rekayasa Perangkat Lunak Terstruktur Dan Beorientasi Objek. Penerbit Informatika. Bandung.

[10] Hars, B., Khanna, E dan Sudha. (2014). Black Box Testing based on Requirement Analysis and Design Specifications. International Journal of Computer Applications (0975 - 8887). Volume 87 No.18, (February). 